Zeszyty Naukowe Szkoły Głównej Gospodarstwa Wiejskiego w Warszawie Problemy Rolnictwa Światowego tom 17 (XXXII), zeszyt 3, 2017: 111-127

DOI: $10.22630 /$ PRS.2017.17.3.58

Barbara Hadryjańska ${ }^{1}$

Uniwersytet Przyrodniczy w Poznaniu

Jacek Mrowicki ${ }^{2}$

INC Rating

\title{
Obligacje przychodowe jako narzędzie zwiększające zdolności inwestycyjne gmin wiejskich w Polsce
}

\section{Income Bonds as a Tool to Increase the Investment Capacity of Rural Communities in Poland}

\begin{abstract}
Synopsis. W pracy zaprezentowano zagadnienia związane $\mathrm{z}$ pojęciem gminy jako podstawowej jednostki samorząadu terytorialnego, polityką budżetową oraz finansowaniem inwestycji gminnych przy pomocy obligacji przychodowych. Głównym celem pracy było pokazanie pozabudżetowych sposobów finansowania inwestycji gminnych ze szczególnym uwzględnieniem obligacji komunalnych i przychodowych. Obligacje przychodowe mają wiele zalet jako źródło realizacji inwestycji gminnych w porównaniu $\mathrm{z}$ kredytem lub pożyczką. Są one emitowane $\mathrm{w}$ celu sfinansowania projektów inwestycyjnych lub przedsięwzięć, z których dochody mają stanowić źródło spłaty tych emisji. Z punktu widzenia oceny ryzyka inwestycyjnego obligacje przychodowe, podobnie jak i ogólnie obligacje komunalne, są zaliczane do najbardziej bezpiecznych papierów wartościowych, co wynika z publicznoprawnego statusu jednostki samorządowej. Istotnym atrybutem emitenta komunalnego jest fakt, że jednostka samorządowa nie może zbankrutować. Przeprowadzone badania ankietowe wśród 132 gmin wiejskich w Polsce pokazały, że podstawowym źródłem pozabudżetowego finansowania dla gmin są dotacje unijne oraz kredyt i pożyczka. Gminy nie korzystają z obligacji przychodowych (oprócz dwóch), ponieważ nie mają wiedzy na temat takiego instrumentu finansowego, a także obawiają się nadmiernego zadłużenia gminy. Wydaje się, że ważnym powodem takiego stanu rzeczy jest ostrożność gmin oraz niechęć do korzystania z instrumentów, które nie są im dobrze znane.
\end{abstract}

Slowa kluczowe: gmina wiejska, obligacje komunalne, obligacje przychodowe, działalność inwestycyjna gmin

\begin{abstract}
The paper presents issues related to the notion of the municipality as a basic unit of local selfgovernment, budgetary policy and financing of municipal investments with the use of revenue bonds. The main purpose of the work was to show non-financial ways of financing municipal investments with special regard to municipal bonds and revenue. Income bonds have many advantages as source for the implementation of municipal investment compared to a loan. They are issued to finance investment projects or projects from which revenue have to be the source of repayment of those issues. From the point of view of investment risk assessment, revenue bonds, as well as municipal bonds in general, are classified as the safest securities, which results from the publicly-regulated status of a local government unit. The essential attribute of a municipal issuer is the fact that a self-government unit cannot go bankrupt. The conducted survey among 132 rural communes in Poland showed that the main source of extra-budget financing for communes are EU subsidies and loans. Communes do not use revenue bonds (except for two) because they do not know about such a financial instrument, and they also worry about the excessive debt of the municipality. It seems that an important reason for this is the caution of the communes and the reluctance to use instruments that are not well known to them.
\end{abstract}

Key words: rural community, municipal bonds, revenue bonds, investment activity of communities

\footnotetext{
${ }^{1}$ dr hab., Katedra Ekonomii UP w Poznaniu, ul. Wojska Polskiego 28, 60-637 Poznań,

e-mail: hadryjanska@up.poznan.pl

${ }^{2}$ mgr, INC Rating, ul. Krasińskiego 16, 60-830 Poznań, e-mail: jmrowicki@onet.pl
} 


\section{B. Hadryjańska, J. Mrowicki}

\section{Wstęp}

Jednym $\mathrm{z}$ przejawów procesów decentralizacyjnych jest wzrastające znaczenie samorządu terytorialnego, który przez współczesne państwa demokratyczne traktowany jest jako system zwiększający sprawność zarządzania zadaniami publicznymi. Efektywność gospodarowania jednostek samorządu terytorialnego (JST) znacznie przewyższa efektywność gospodarowania pozostałych struktur systemu finansów publicznych (Dylewski, Filipiak i in., 2014). Decentralizację w Polsce zapewnia Konstytucja, która wskazuje, że to samorząd terytorialny stanowi formułę decentralizacji władzy publicznej (Konstytucja, art. 16 ust. 1).

Reforma samorządowa dokonana Polsce w latach 90. XX wieku to przykład jednej z najbardziej udanych reform, jakie udało się przeprowadzić w naszym kraju w warunkach gospodarki rynkowej. W efekcie tej reformy wprowadzono trzystopniową strukturę podziału terytorialnego. Obok istniejących gmin - jako zasadniczych jednostek tego podziału, na mapie administracyjnej Polski utworzono 16 województw, 308 powiatów i 65 miast na prawach powiatów (Ustawa $\mathrm{z}$ dnia 5 czerwca 1998 r. o samorządzie powiatowym, Rozporządzenie Rady Ministrów z dnia 7 sierpnia 1998 r. w sprawie utworzenia powiatów). $\mathrm{Z}$ dniem 1 stycznia 2002 r. ustanowiono kolejnych 7 powiatów, a w połowie marca tegoż roku utworzono powiat grodzki Warszawa i zniesiono powiat ziemski warszawski (Samorząd powiatowy w Polsce - raport ZPP 2013).

Samorząd stanowi sam w sobie instrument uspołecznienia władzy publicznej, a jego najbardziej demokratyczną formą jest samorząd terytorialny. Warto pamiętać o tym, że ma on nie tylko charakter administracyjny, lecz jest zjawiskiem politycznym i może funkcjonować tylko w warunkach ustroju demokratycznego (Izdebski, 2009).

Samorząd terytorialny zarówno z punktu widzenia społecznego, jak i ekonomicznego pełni istotną rolę $\mathrm{w}$ gospodarce. Stan ten determinowany jest misją, zakresem działania i specyfiką funkcjonowania jednostek samorządu terytorialnego. Idea funkcjonowania samorządu terytorialnego sprowadza się do realizacji koncepcji społeczeństwa obywatelskiego i samorządnego, a także ma wymiar praktyczny, wyrażający się szczególnie poprzez pryzmat efektywności działania. Aspekt ekonomiczny w działalności JST przejawia się poprzez fakt, że samorząd terytorialny w gospodarce oprócz tego, że kreuje popyt na dobra i usługi, jest również podmiotem odpowiedzialnym za zaspokojenie potrzeb zgłaszanych przez społeczności lokalne (Zioło, 2016).

Jednak, żeby te potrzeby mogły być zrealizowane poprzez działalność JST, niezbędne są środki finansowe, które w budżecie takich jednostek stanowią ich dochody mające charakter dochodów własnych, dotacji celowych i subwencji. Stanowią one źródło pokrycia bieżących wydatków niezbędnych do realizacji zadań spoczywających na samorządzie. Dla spełnienia wszystkich potrzeb mieszkańców lokalnych, niezbędne jest realizowanie przedsięwzięć inwestycyjnych, które decydują o stopniu rozwoju JST. Do ich realizacji potrzebne są dodatkowe źródła finansowania, którymi mogą być pożyczki, kredyty, środki pochodzące $\mathrm{z}$ budżetu Unii Europejskiej, a także dochody z posiadanych papierów wartościowych.

Celem pracy jest zaprezentowanie warunków, w których funkcjonują gminy, zwłaszcza gminy wiejskie, jako podstawowe jednostki samorządu terytorialnego, ukazanie możliwości finansowania ich zadań inwestycyjnych, ze szczególnym uwzględnieniem specyficznego źródła dochodów, jakim jest emisja obligacji komunalnych i przychodowych. Założeniem opracowania jest teza, że doskonałym instrumentem służącym do zwiększania możliwości 
inwestycyjnych gmin wiejskich są obligacje przychodowe, z których w bardzo niewielkim stopniu korzystają te podmioty, a które w świetle kończących się już w ciągu kilku najbliższych lat bezzwrotnych środków pomocowych z Unii Europejskiej, mogą stanowić podstawowe źródło finansowania inwestycji.

W pracy zostaną zaprezentowane wyniki badań empirycznych przeprowadzonych na terenach gmin wiejskich, dotyczących pozabudżetowych sposobów finansowania inwestycji samorządowych, ze szczególnym uwzględnieniem obligacji przychodowych.

\section{Gmina jako podstawowa jednostka samorządu terytorialnego}

Samorząd jest jedną z postaci administracji zdecentralizowanej, i jak głosi Konstytucja (art. 16) „ogół mieszkańców zasadniczego podziału terytorialnego stanowi z mocy prawa wspólnotę samorządową." Przepisy prawa gwarantują określonym grupom społecznym i wyłonionym przez nie organom prawo do zarządzania jej sprawami. Grupy te uczestniczą w wykonywaniu samorządu obligatoryjnie z mocy ustawy, przy czym wykonują zadania leżące w gestii administracji publicznej. Posiadają własną organizację o charakterze przedstawicielskim, pozostającą pod kontrolą tej grupy społecznej, która ją wybrała. Organy samorządu, nie będąc organami administracji państwowej, wchodzą jednak w skład jednolitego aparatu administracyjnego jako całości (Bukowski, Jędrzejewski, Rączka, 2003).

Pojęcie samorządu od dawna jest łączone z gminą i w znaczeniu prawnym samorząd rozumiany jest ,jako wykonywanie zadań administracji publicznej w sposób samodzielny i na własną odpowiedzialność przez odrębne w stosunku do państwa podmioty, które nie są w zakresie swoich zadań poddane ingerencji państwowej” (Pająk, 2011). W znaczeniu politycznym samorząa „oznacza honorowe uczestnictwo osób fizycznych w wykonywaniu określonych zadań państwowych” (Dolnicki, 2009). Natomiast samorząd terytorialny w sensie prawnym i gospodarczym traktowany jest jako ,podmiot prawa publicznego dysponujący prawem do wydawania decyzji administracyjnych i jako podmiot prawa cywilnego, czyli odrębna od skarbu państwa osoba prawa cywilnego, posiadająca odrębną własność" (Zioło, 2016).

Polskie prawo samorządu terytorialnego, gwarantowane zapisem konstytucyjnym, jest zgodne z Europejską Kartą Samorządu Terytorialnego (EKST) ratyfikowaną przez Polskę 22 listopada 1993 r. (Oświadczenie Rządowe z dnia 14 lipca 1994 r.). Karta ta jest wyrazem dążeń do ujednolicenia rozwiązań samorządowych w skali europejskiej, zapewniając współdziałanie w sprawach lokalnych na drodze demokratycznej, z zachowaniem odrębności wynikającej z dziedzictwa kulturowego poszczególnych społeczeństw (Kozuń-Cieślak, 2008). Karta wskazuje, że zasady samorządu lokalnego są określane w wewnętrznych przepisach prawnych i w miarę możliwości w konstytucjach. W dokumencie znaleźć też można zapewnienie, że samorząd komunalny oznacza prawo i faktyczną możność komunalnych korporacji lokalnych do regulowania i kształtowania w ramach ustaw znacznej części spraw publicznych, na własną odpowiedzialność, dla dobra mieszkańców (Europejska Karta Samorządu Terytorialnego, 1994).

Konstytucja RP stanowi, że gmina jest podstawową jednostką samorządu terytorialnego, a jej mieszkańcy z mocy prawa tworzą wspólnotę samorządową. Gmina jest prawnie zorganizowanym terytorialnym związkiem osób, który posiada odrębną od państwa osobowość prawną podlegającą ochronie sądowej. Tworzenie, łączenie, podział i znoszenie gmin, ustalanie ich granic oraz nazw i siedzib następuje w drodze rozporządzenia Rady 


\section{B. Hadryjańska, J. Mrowicki}

Ministrów po uprzedniej konsultacji z jej mieszkańcami. Ponadto należy dążyć do tego, aby gmina obejmowała obszar możliwie jednorodny ze względu na układ osadniczy i przestrzenny oraz więzi społeczne, gospodarcze i kulturowe oraz zapewniający zdolność wykonywania zadań publicznych (Pająk, 2011).

Ustawa o samorządzie gminnym w art. 2 stwierdza, że gmina posiada osobowość prawną i wykonuje zadania publiczne we własnym imieniu i na własną odpowiedzialność, a jej samodzielność podlega ochronie sądowej. Zadaniami użyteczności publicznej są zadania własne gminy, określone w art. 7 ust. 1, których celem jest bieżące i nieprzerwane zaspokajanie zbiorowych potrzeb ludności $\mathrm{w}$ drodze świadczenia usług powszechnie dostępnych. Do zakresu działań gminy zgodnie z art. 6 ust. 1 ustawy należą wszystkie sprawy publiczne o znaczeniu lokalnym, o ile nie zostały zastrzeżone ustawami na rzecz innych podmiotów.

Zadania gminy można klasyfikować wykorzystując różne kryteria, z których podstawowymi są: kryterium przynależności i powszechności. Uwzględniając kryterium przynależności, zadania gminy można podzielić na własne, zlecone i powierzone (KozuńCieślak, 2008). O zadaniach własnych mówi się, gdy mają one charakter lokalny oraz ich wykonywanie jest finansowane przez gminę, która działa względnie samodzielnie, we własnym imieniu (Fleszer, 2011). Zadania własne są związane z (Pająk, 2011):

- infrastrukturą techniczną (drogi, wodociągi, komunikacja publiczna),

- infrastrukturą społeczną (szkolnictwo, ochrona zdrowia, opieka społeczna),

- porządkiem i bezpieczeństwem publicznym (np. ochrona prawa),

- ładem przestrzennym i ekologią (planowanie przestrzennego zagospodarowania, ochrona środowiska).

Dokładne wyszczególnienie zadań własnych realizowanych przez gminę znajduje się w art. 7 ust. 1 Ustawy o samorządzie gminnym.

Zadania zlecone są przekazywane gminom na mocy obowiązującego prawa. Są to zadania z zakresu administracji rządowej (np. przygotowanie, zorganizowanie i przeprowadzenie spisu na terenie gminy; przyznawanie i wypłacanie zasiłków celowych na pokrycie wydatków związanych z klęską żywiołową lub ekologiczną), a także z zakresu organizacji przygotowań i przeprowadzenia wyborów powszechnych oraz referendów. Finansowanie związane z realizacją zadań zleconych pochodzi z organu administracji, który je zleca (Ofiarski, 2010). Granica dopuszczalności przekazywania gminie zadań przez państwo zamyka się pomiędzy „,zaspokajaniem zbiorowych potrzeb wspólnoty” a ,sprawami publicznymi o znaczeniu lokalnym". Wszystkie inne sprawy publiczne należą zatem do administracji państwowej (Dolnicki, 2009).

Obok zadań własnych i zleconych funkcjonuje także kategoria zadań powierzonych, rozumianych jako zadania przekazane do wykonania gminom w drodze umów lub porozumień między jednostkami samorządu terytorialnego oraz między jednostką samorządu terytorialnego a administracją rządową. Zakres zadań powierzonych oraz sposób ich finansowania określają umowy, które najczęściej dotyczą realizacji usług komunalnych w obszarze: gospodarki wodno-kanalizacyjnej, edukacji, przedsięwzięć gospodarczych, pomocy społecznej, kultury, turystyki itp. (Zioło, 2016).

Biorąc pod uwagę kryterium powszechności, zadania gminy można podzielić na obligatoryjne i fakultatywne. Zadania obligatoryjne mogą być zarówno własne, jak i zlecone. Są one przydzielane gminom na podstawie przepisów prawa i wobec tego są powszechnie obecne (Kozuń-Cieślak, 2008). Wśród zadań, jakie realizują gminy jako obligatoryjne, 
można wymienić: administracyjne, ochronę zdrowia, edukację publiczną, wspieranie rodzin, pomoc społeczną, utrzymanie porządku publicznego i bezpieczeństwa obywateli, zapewnienie ochrony przeciwpożarowej i przeciwpowodziowej, zapewnienie bezpieczeństwa ekologicznego (usuwanie nieczystości, odpadów, utrzymanie czystości), utrzymanie gminnych obiektów i urządzeń użyteczności publicznej oraz obiektów administracyjnych, tworzenie i utrzymanie podstawowej infrastruktury publicznej (drogi, mosty, wodociągi, kanalizacja, urządzenia sanitarne, piesze i rowerowe ciągi komunikacyjne itp.) (Gonet, 2016). Za zadania fakultatywne uważa się wszystkie zadania, które nie mają prawnej obligatoryjności i wobec tego mogą występować tylko w niektórych gminach. O fakultatywnym charakterze zadań gmin decyduje porozumienie stron lub wola gminy, która podjęła się wykonywania dodatkowych zadań (Kozuń-Cieślak, 2008). Zadania te mogą dotyczyć realizacji przedsięwzięć inwestycyjnych, które nie są związane z podstawową infrastrukturą publiczną (np. gminne budownictwo mieszkaniowe), tworzenia urządzeń sportowych i rekreacyjnych, funkcjonowania gminnych instytucji kultury itp. (Gonet, 2016).

\section{Polityka budżetowa gminy}

Polityka budżetowa gminy jest to celowa działalność, która dotyczy gromadzenia i wydatkowania środków pieniężnych oraz wyboru odpowiednich metod i narzędzi umożliwiających zrealizowanie określonych celów społeczno-gospodarczych. W jej skład wchodzi polityka dochodowa, polityka wydatkowa oraz polityka równoważenia budżetu. Całość tej polityki powinna służyć zaspokajaniu potrzeb publicznych wspólnoty samorządowej oraz kreować rozwój lokalny. Polityka budżetowa gminy powinna cechować się przejrzystością, czyli przede wszystkim powinno to oznaczać dostęp do informacji o działalności przeszłej, obecnej i przyszłej organów i podmiotów związanych z tą polityką, a także jasno określony obszar obowiązków i odpowiedzialności gminy, konkretnie wyznaczone cele i zadania oraz rzetelność i terminowość w zakresie realizacji zadań i przekazywanych informacji (Kotowska, 2016).

Najważniejszymi aktami prawnymi, regulującymi gospodarkę finansową gminy są: Konstytucja RP, ustawa o dochodach jednostek samorządu terytorialnego, ustawa o samorządzie gminnym, ustawa prawo zamówień publicznych, ustawa o odpowiedzialności za naruszenie dyscypliny finansów publicznych, ustawa o podatkach i opłatach lokalnych (Ziółkowska, 2012).

Każda jednostka samorządu terytorialnego prowadzi gospodarkę finansową na podstawie budżetu. „Budżet gminy jest to opracowany, uchwalony i wykonywany w sposób przewidziany prawem, roczny plan finansowy gminy, obejmujący dochody wraz z przeznaczonymi na pokrycie planowanego niedoboru wpływami zwrotnymi, ustawowo określonymi, oraz wydatkami na finansowanie zadań własnych i na zadania zlecone gminy, na podstawie którego prowadzi ona w sposób jawny i samodzielny swą gospodarkę finansową" (Jędrzejewski, 2007). Prawną definicję budżetu gminy zawiera art. 165 ust. 1 ustawy o finansach publicznych. Jest on określony jako: ,roczny plan dochodów i wydatków oraz przychodów i rozchodów".

Budżet gminy będąc ważnym narzędziem zarządzania finansowego, służy planowaniu, wykonywaniu i kontrolowaniu operacji finansowych. Umożliwia rozliczenie gminy z jej działalności i jest łącznikiem władz ze społeczeństwem (Sadowska, 2011). 


\section{B. Hadryjańska, J. Mrowicki}

Zastosowanie pojęcia dochodów i wydatków budżetowych pozwala w konstrukcji budżetu na ustalenie jego wyniku (deficytu, nadwyżki lub stanu równowagi), który jest obliczony jako różnica między dochodami a wydatkami. Przychody finansują deficyt budżetowy danego roku oraz spłaty wcześniej zaciągniętych zobowiązań. Budżet jako plan finansowy odnosi się do przyszłości, stad też oznaczenie w nim wielkości dochodów i przychodów ma charakter prognozy, która jest obciążona ryzykiem niepełnej realizacji (Kornberger-Sokołowska, 2010).

Ustawa o dochodach JST określa źródła dochodów oraz zasady ustalania i gromadzenia tych dochodów, jak również zasady ustalania i przekazywania subwencji ogólnej i dotacji celowych z budżetu państwa oraz wymienia, jakie dochody stanowią dochody JST. Dochodami tymi są: dochody własne, subwencja ogólna, dotacje celowe z budżetu państwa.

Źródłami dochodów własnych gminy, czyli dochodami obligatoryjnymi są (Dolnicki, 2009):

1. wpływy z podatków: od nieruchomości, rolnego, leśnego, od środków transportowych, dochodowego od osób fizycznych, opłacanego w formie karty podatkowej, od spadków i darowizn, od czynności cywilnoprawnych;

2. wpływy z opłat: skarbowej, targowej, miejscowej, uzdrowiskowej, od posiadania psów, eksploatacyjnej;

3. dochody uzyskiwane przez gminne jednostki budżetowe gminy oraz wpłaty od gminnych zakładów budżetowych i gospodarstw pomocniczych gminnych jednostek budżetowych;

4. dochody z majątku gminy;

5. spadki, zapisy i darowizny na rzecz gminy;

6. dochody z kar pieniężnych i grzywien określonych w odrębnych przepisach;

7. 5\% dochodów uzyskiwanych na rzecz budżetu państwa $\mathrm{w}$ związku $\mathrm{z}$ realizacją zadań z zakresu administracji rządowej;

8. odsetki od pożyczek udzielanych przez gminę;

9. odsetki od nieterminowo przekazywanych należności stanowiących dochody gminy;

10. odsetki od środków finansowych gromadzonych na rachunkach bankowych gminy;

11. dotacje z budżetów innych jednostek samorządu terytorialnego;

12. subwencja ogólna;

13. udziały $\mathrm{w}$ podatkach stanowiących dochód budżetu państwa (wpływy z podatku dochodowego od osób fizycznych, z podatku dochodowego od osób prawnych);

Dochodami fakultatywnymi są: środki pochodzące ze źródeł zagranicznych niepodlegające zwrotowi, środki pochodzące z budżetu Unii Europejskiej oraz inne środki określone w odrębnych przepisach (Kozuń-Cieślak, 2008).

Subwencja ogólna jest źródłem środków finansowych dla zadań samorządowych z dziedziny oświaty oraz służy finansowemu wsparciu ekonomicznemu słabszych jednostek samorządu terytorialnego. Ma ona charakter dochodów ogólnych i składa się z kilku części:

- części oświatowej, którą otrzymują gminy, powiaty i województwa;

- części wyrównawczej i równoważącej, przeznaczonej dla gmin i powiatów;

- części regionalnej, przekazywanej województwom.

Znaczne zróżnicowanie dochodów poszczególnych jednostek samorządu terytorialnego spowodowało konieczność wprowadzenia do ustawy nowego instrumentu wyrównywania dysproporcji dochodowych. Polega on na dokonywaniu tzw. wpłat, nie tylko przez gminy, ale i przez powiaty i województwa. Środki z wpłat w ramach działania mechanizmu 
solidarnościowego, wpływają do budżetu państwa, a następnie są przekazywane jednostkom samorządu terytorialnego o słabszej kondycji finansowej (Ziółkowska, 2012).

Do fakultatywnych źródeł dochodów gminy należy zaliczyć dotacje celowe z budżetu państwa na (Dolnicki, 2009):

1. zadania $\mathrm{z}$ zakresu administracji rządowej oraz na inne zadania zlecone ustawami,

2. zadania realizowane przez jednostki samorządu terytorialnego na mocy porozumień zawartych z organami administracji rządowej,

3. usuwanie bezpośrednich zagrożeń dla bezpieczeństwa i porządku publicznego, skutków powodzi i osuwisk ziemnych oraz skutków innych klęsk żywiołowych,

4. finansowanie lub dofinansowanie zadań własnych,

5. realizację zadań wynikających z umów międzynarodowych.

Dotacje celowe dla gmin muszą być wykorzystywane zgodnie z przeznaczeniem, natomiast niewykorzystane podlegają zwrotowi do budżetu państwa. Są one dla władz państwowych bardzo dogodnym i skutecznym instrumentem wpływania na samorząd terytorialny (Jędrzejewski, 2007). Środki dotacji uzyskiwane są na wniosek samorządu, a kryteria ich przyznawania w wielu przypadkach są uznaniowe (Pastuszka, 2016).

Do realizacji swoich zadań gmina może wykorzystywać inne źródła finansowania o charakterze zwrotnym, czyli pożyczki, kredyty, emisję i sprzedaż papierów wartościowych. Kredyty i pożyczki są ważnym elementem funkcjonowania gmin, z którego gminy korzystają najczęściej, ponieważ stanowią dogodne źródło pozyskiwania niezbędnych środków na cele inwestycyjne. Ważnym źródłem dochodów gminy mogą być dochody z majątku i praw majątkowych, na które organy gminy mają największy wpływ. Wpływ ten przejawia się przede wszystkim w możliwości ustalania ich rodzajów i wielkości. Mienie gminy jest odrębne i niepowiązane ani z mieniem Skarbu Państwa, ani z mieniem innych jednostek samorządu terytorialnego, w związku z czym gmina może sama decydować o jego przeznaczeniu i wykorzystaniu. Dochodami gminy $\mathrm{z}$ tytułu gospodarowania nieruchomościami będącymi jej własnością mogą być przede wszystkim wpływy z tytułu obrotu nieruchomościami, czyli związane $\mathrm{z}$ ich sprzedażą, zamianą, zrzeczeniem się, oddaniem w użytkowanie wieczyste, w najem lub dzierżawę, użyczenie, oddaniem w trwały zarząd (Dolnicki, 2009).

Największe znaczenie w strukturze dochodów gmin w Polsce mają jednak dochody własne $(44,1 \%$ ); subwencje stanowią $25,8 \%$, a dotacje to $30,1 \%$ wszystkich dochodów (Sprawozdanie z wykonania budżetu państwa za 2016).

Polityka finansowa realizowana przez gminy obejmuje nie tylko stronę dochodową, ale w znacznym stopniu obejmuje ona wydatki. Polityka wydatkowa gmin polega na świadomym i celowym określaniu kierunków rozdysponowania środków publicznych w celu realizacji zadań jednostki. Przedmiotem polityki wydatkowej jest ustalanie kryteriów dokonywania wydatków oraz zakresu i kolejności wykonywanych zadań, a także podmiotów, które będą te zadania realizować oraz jakimi metodami (Jędrzejewski, 2007).

Pojęcie wydatków, zasady ich klasyfikacji oraz przeznaczenie zawarte są w art. 42 Ustawy o finansach publicznych. Zgodnie $\mathrm{z}$ art. 42 oraz art. 44 tej Ustawy wydatki dokonywane przez jednostki samorzadu terytorialnego sa wydatkami publicznymi i musza być ponoszone na cele $\mathrm{i}$ w wysokościach ustalonych $\mathrm{w}$ uchwale budżetowej jednostki samorządu terytorialnego oraz w planie finansowym jednostki sektora finansów publicznych. Jednostki sektora finansów publicznych dokonują wydatków zgodnie z przepisami dotyczącymi poszczególnych rodzajów wydatków (Ofiarski, 2010). 


\section{B. Hadryjańska, J. Mrowicki}

W ramach wydatków budżetu danego samorządu wyszczególnia się - w układzie działów i rozdziałów klasyfikacji budżetowej - kwoty wydatków bieżących i wydatków majątkowych. Do wydatków majątkowych wspomniana powyżej Ustawa zalicza wydatki na: inwestycje i zakupy inwestycyjne, w tym na programy finansowane z udziałem środków UE, zakup i objęcie akcji lub udziałów, wniesienie wkładów do spółek prawa handlowego. Wydatki bieżące to wydatki nie zaliczone do wydatków majątkowych. W systemie wydatków bieżących wyodrębnia się: wydatki jednostek budżetowych, dotacje na zadania bieżące, świadczenia na rzecz osób fizycznych, wypłaty z tytułu poręczeń i gwarancji, obsługę długu (Borodo, 2014).

Największe znaczenie w polityce wydatkowej gmin mają wydatki bieżące, które stanowią nawet ponad $80 \%$ całkowitej kwoty wydatków, a pozostała część jest związana z wydatkami majątkowymi (według Sprawozdania z wykonania budżetu państwa za 2016 r., wydatki bieżące stanowiły $87 \%$, a wydatki majątkowe 13\% wśród wszystkich wydatków). Analiza wydatków budżetowych w gminach pozwala również stwierdzić, że przeważają w nich wydatki na gospodarkę komunalną, opiekę społeczną oraz oświatę i wychowanie (Jędrzejewski, 2007).

Trzecim elementem polityki budżetowej gmin jest polityka równoważenia budżetu, polegająca na założeniu, że dochody jednostek muszą pokrywać ich wydatki. W takiej komfortowej sytuacji dla gminy nie występuje deficyt, który należy rozumieć jako niemożność sfinansowania całości wydatków publicznych dochodami pozostającymi w dyspozycji jednostki. Deficyt jest najczęściej definiowany jako ujemna różnica między dochodami publicznymi a wydatkami publicznymi. Sytuacją przeciwną do powstania deficytu budżetu jest nadwyżka, występująca w sytuacji, gdy wydatki publiczne są mniejsze od dochodów (Wernik, 2014). Zgodnie z Ustawą o finansach publicznych deficyt może być sfinansowany przychodami pochodzącymi ze sprzedaży papierów wartościowych wyemitowanych przez gminę, z kredytów i pożyczek, z prywatyzacji majątku oraz z nadwyżki budżetu z lat ubiegłych i z wolnych środków (Ziółkowska, 2012).

\section{Finansowanie inwestycji gminnych za pomocą instrumentów dłużnych, ze szczególnym uwzględnieniem obligacji przychodowych}

Zewnętrznymi źródłami finansowania działalności gmin o charakterze zwrotnym są kredyty, pożyczki, emisje obligacji, a także środki pochodzące ze specjalnych instytucji międzynarodowych. Bardzo istotna, z punktu widzenia zasadności podejmowania decyzji w aspekcie wykorzystywania źródeł zewnętrznych, jest właściwa ocena i analiza doboru tych strumieni. Z tego względu dobór zewnętrznego źródła finansowania powinien być uzależniony m.in. od: istniejących ograniczeń prawnych i budżetowych, kosztu kapitału, elastyczności instrumentu dłużnego, ryzyka związanego z pozyskaniem kapitału, przedmiotu finansowania, dostępności źródeł finansowania, szybkości pozyskania kapitału, okresu zwrotu kapitału i zabezpieczenia jego zwrotu, a także od efektu promocyjnego (Śliwiński, 2009; Dylewski, Filipiak i in., 2014).

Najpopularniejszą i najszerzej wykorzystywaną dotychczas formą zaciągania długu przez jednostki samorządu terytorialnego w Polsce jest kredyt bankowy i pożyczki, które stanowią około 90\% wartości zobowiązań ogółem tych jednostek (Informacja o stanie zobowiązań jednostek samorządu terytorialnego wg tytułów dłużnych w latach 2010 - 2 kwartały 2012). Jednak w ostatnich latach wzrosło zainteresowanie gmin 
alternatywnym sposobem finansowania długoterminowego, jakim jest emisja papierów dłużnych, czyli obligacji komunalnych. Jest to szczególny rodzaj pożyczki dający jednostkom samorządu terytorialnego więcej swobody niż kredyt bankowy, gdyż jednostki te mogą poszukać środków wśród wielu zainteresowanych tą formą inwestowania kapitału podmiotów, unikając tym samym pośredników. Obligacja różni się od kredytu następującymi cechami (Jędrzejewski, 2007):

- jest papierem dłużnym, odmiennie uregulowanym prawnie,

- w przypadku obligacji występuje wielu wierzycieli, przy kredycie z reguły jeden,

- w razie emisji obligacji rola banku jest ograniczona, przy kredycie zaś warunki umowy kredytowej zależne są od banku,

- zwrot długu z obligacji najczęściej następuje jednorazowo na koniec emisji, natomiast kredyt spłacany jest zazwyczaj w ratach,

- emitent obligacji samodzielnie kształtuje warunki emisji, podczas gdy warunki kredytu zależą od kredytobiorcy.

W 2000 roku dokonano nowelizacji ustawy o obligacjach, wprowadzając możliwość emitowania tych obligacji przez jednostki samorządu terytorialnego (Ustawa z dnia 29 czerwca 1995 r. o obligacjach). Od 2015 roku obowiązuje nowa ustawa, która w art.4 ust. 1 określa obligacje jako papier wartościowy emitowany w serii, w którym emitent stwierdza, że jest dłużnikiem właściciela obligacji (obligatariusza) i zobowiązuje się wobec niego do spełnienia określonego świadczenia (Ustawa z dnia 15 stycznia 2015 r. o obligacjach). Inaczej mówiąc, obligacje są wierzycielskimi papierami wartościowymi emitowanymi przez osoby prawne w celu pozyskania środków pieniężnych dla sfinansowania określonych celów - najczęściej konkretnych inwestycji. Emitent zobowiązuje się do regulowania płatności odsetkowych oraz do spłaty pożyczki obligacyjnej w dniu jej wykupu.

Instrumentem dłużnym dla jednostek samorządu terytorialnego są także euroobligacje, które w stosunku do obligacji emitowanych na rynkach krajowych posiadają dodatkowo szczególne zalety wynikające $\mathrm{z}$ eksterytorialnego charakteru emisji. Euroobligacje są emitowane na rynkach kapitałowych jednocześnie w różnych krajach, a więc są kierowane do grona inwestorów międzynarodowych, dzięki czemu unikają rejestracji i kontroli nakładanej na nowe emisje na narodowych rynkach finansowych. Ponadto są to papiery wartościowe, których konstrukcja wiążę się z płatnościami odsetkowymi, a odsetki są płacone brutto i nie podlegają opodatkowaniu. W przypadku euroobligacji inwestor nie jest zaangażowany $\mathrm{w}$ sposób, $\mathrm{w}$ jaki emitent prowadzi swoje finanse. Euroobligacje sa rejestrowane na jednej lub więcej giełdach, a ich rynek nie podlega bezpośredniej kontroli narodowych lub międzynarodowych władz monetarnych, co powoduje, że rozwija się on w myśl zasad w pełni swobodnej konkurencji. Dlatego jedynym czynnikiem regulującym ten rynek jest stopa procentowa, która kształtuje się pod wpływem popytu i podaży (KozuńCieślak, 2008).

Jednym z typów obligacji są obligacje komunalne, które można zdefiniować jako papiery wartościowe $\mathrm{w}$ randze długu publicznego emitowane przez jednostki samorządu terytorialnego $\mathrm{w}$ celu finansowania projektów inwestycyjnych realizowanych $\mathrm{w}$ ramach zadań, do wypełnienia których te jednostki zostały ustawowo powołane. W ramach obligacji komunalnych wyróżnić można obligacje przychodowe, które są emitowane w celu sfinansowania projektów inwestycyjnych lub przedsięwzięć, z których dochody mają stanowić źródło spłaty tych emisji. Prawo do emisji tych obligacji mają gminy, powiaty, województwa, a także związki tych jednostek oraz miasto stołeczne Warszawa (Kozuń- 
Cieślak, 2008). Z tego instrumentu dla zdobycia środków inwestycyjnych jednostki samorząa terytorialnego nie korzystają jednak często. Zaledwie $8,5 \%$ stanowiły w roku 2012 zobowiązania $\mathrm{z}$ tytułu papierów wartościowych w stosunku do wszystkich tytułów dłużnych, czyli pożyczek, kredytów i zobowiązań wymagalnych (Zobowiązania według papierów dłużnych jednostek samorządu terytorialnego wg tytułów dłużnych w latach 20102 kwartały 2012).

Obligacje przychodowe są pierwszym papierem dhużnym, który został wprowadzony wyłącznie w celu pozyskiwania środków na realizację inwestycji JST. U źródła kreacji obligacji przychodowych legło głębokie przeświadczenie, że dotychczasowe rozwiązania prawne regulujące emitowanie papierów dłużnych (obligacji) przez podmioty komunalne były niewystarczające ze względu na dwie główne bariery. Pierwszą z nich stanowiły zapisy w ustawie o obligacjach przed jej nowelizacją, które zamiast przyczynić się do rozwoju rynku papierów dłużnych, hamowały rozwój rynku kapitałowego w Polsce, w tym również emisji obligacji komunalnych. Drugą barierą był brak takiej kategorii obligacji dla instytucji komunalnych, której emisja powiązana byłaby z konkretną inwestycją, a dochody z tej inwestycji kierowane byłyby na spłatę zobowiązań wynikających z tych obligacji (Śliwiński, Ostrowski, Stępniewski, 2005).

Emisja obligacji przychodowych może przebiegać w trybie emisji niepublicznej lub w drodze oferty publicznej. Wybór trybu emisji tych obligacji może być oparty na kilku przesłankach, które należy rozpatrywać łącznie. Pierwszą $\mathrm{z}$ nich jest określenie potencjalnego popytu na obligacje i związanego z nim kręgu nabywców obligacji poprzez skierowanie emisji do indywidualnego oznaczonego adresata poniżej 149 osób (emisja niepubliczna) albo nieoznaczonego adresata lub powyżej 150 osób (emisja publiczna). Drugą przesłankę stanowi oszacowanie kosztów emisji, które w przypadku emisji publicznej mogą kształtować się na wyższym poziomie w stosunku do emisji niepublicznej. Trzeci czynnik determinujący wybór charakteru emisji obligacji JST stanowi określenie okresu zapadalności obligacji $\mathrm{W}$ związku ze specyfiką określonego celu emisji. Jeżeli celem emisji jest sfinansowanie przedsięwzięcia pojawia się czynnik ryzyka, iż obligacje krótkoterminowe o okresie zapadalności poniżej jednego roku mogą okazać się niewystarczające do sfinansowania tego przedsięwzięcia. Obligacje o krótkoterminowym cyklu inwestycyjnym mogą natomiast stanowić odpowiedni sposób pozyskania kapitału na inwestycje o charakterze modernizacyjnym przy wykorzystaniu obecnie już istniejących środków trwałych (Chojecka, Ostrowski, Stępniewski, 2009b).

Gmina, podejmując decyzję o emisji papierów wartościowych, ma możliwość uplasowania emisji (Filipiak, 2016):

- na Catalyst, stanowiącym system obrotu i autoryzacji instrumentów dłużnych na rynkach regulowanych i alternatywnych; segment handlu hurtowego prowadzi spółka BondSpot, segment detaliczny prowadzony jest przez Giełdę Papierów Wartościowych (GPW),

- za pomocą organizatora emisji, którymi mogą być banki lub domy maklerskie na rynku krajowym lub zagranicznym

Rynek emisji obligacji komunalnych Catalyst ma tę zaletę, że umożliwia plasowanie emisji na rynku regulowanym $\mathrm{i}$ alternatywnym, $\mathrm{w}$ obszarze handlu detalicznego i hurtowego. Decyzja o wykorzystaniu rynku Catalyst ogranicza rolę banków i domów maklerskich, która sprowadza się do czynności doradczych. Bank lub dom maklerski mogą dokonać weryfikacji możliwości finansowych gmin, w tym jej sytuacji finansowej wraz z oceną zdolności do 
zaciągania zobowiązań oraz analizą wrażliwości. Rola GPW, jak i Bond Spot sprowadza się m.in. do rozpatrzenia wniosku o dopuszczenie i wprowadzenie instrumentów do obrotu na rynku, dokonania oceny, czy gmina faktycznie posiada zdolność do wywiązywania się ze zobowiązań, oceny cech instrumentów będących przedmiotem decyzji o dopuszczeniu do obrotu, analizy okoliczności mogących mieć wpływ na bezpieczeństwo obrotu oraz interes uczestników obrotu, podjęcia decyzji o dopuszczeniu i wykluczeniu z obrotu instrumentów, dokonania weryfikacji wypełniania przez emitentów instrumentów dłużnych wymogów informacyjnych.

Zasady emisji, zbywania, nabywania i wykupu obligacji komunalnych, w tym również przychodowych, reguluje Ustawa o obligacjach. Jednak emisja obligacji komunalnych każdorazowo musi wynikać z upoważnienia zamieszczonego w uchwale budżetowej, która stanowi podstawę gospodarki finansowej samorządu terytorialnego. Bezpośrednią podstawę prawną zaciągnięcia pożyczki obligacyjnej stanowi uchwała o emisji obligacji podjęta przez organy stanowiące jednostek samorządu terytorialnego (Ofiarski, 2010).

Z punktu widzenia oceny ryzyka inwestycyjnego obligacje przychodowe, podobnie jak i ogólnie obligacje komunalne, są zaliczane do najbardziej bezpiecznych papierów wartościowych, co wynika z publicznoprawnego statusu jednostki samorządowej. Istotnym atrybutem emitenta komunalnego jest fakt, że jednostka samorządowa nie może być postawiona w stan upadłości i teoretycznie nie może zbankrutować. Niewątpliwym plusem takich emitentów jest duża wartość ich majątku trwałego, co pozwala na ustanawianie zabezpieczeń, takich jak zastaw czy hipoteka.. Jednostka samorządowa ma określoną samodzielność dochodową wynikającą z władztwa podatkowego. Gospodarka finansowa jednostek samorządowych jest jawna (art. 11 ustawy o finansach publicznych), co ogranicza możliwości manewrowania wydatkami i gwarantuje przejrzystość mechanizmów decyzyjnych. Gwarancję bezpieczeństwa inwestycji dają obligatariuszom również przepisy ustawy o obligacjach, w myśl których środki pochodzące $\mathrm{z}$ emisji gmina nie może przeznaczyć na inne cele niż określone w warunkach emisji. Dodatkowym wzmocnieniem bezpieczeństwa zobowiązań jednostki samorządu mogą być: gwarancje banków polskich i zagranicznych, gwarancje NBP, udzielenie zabezpieczenia przez Skarb Państwa lub międzynarodową instytucję finansową, udzielenie poręczenia przez inną jednostkę samorządu (Kozuń-Cieślak, 2008).

Typowymi elementami treści obligacji emitowanych przez samorządowe jednostki organizacyjne są m.in. nazwa obligacji i cel jej wyemitowania, jeżeli jest określony; wartość nominalna i numer kolejnej obligacji; opis świadczeń emitenta, ze wskazaniem w szczególności wysokości tych świadczeń lub sposobu ich ustalania, terminów, sposobów i miejsc ich spełniania; ewentualny zakaz lub ograniczenie zbywania obligacji imiennej; data, od której oblicza się oprocentowanie, terminy jego wypłaty i miejsce płatności, warunki wykupu; zakres i forma zabezpieczenia albo informacja o jego braku; miejsce i data wystawienia obligacji. Do obligacji dołącza się arkusz kuponowy oprocentowania, jeśli warunki emisji to przewidują, oraz arkusz wykupu obligacji. Można emitować obligacje imienne lub na okaziciela. Emitent może, w warunkach emisji, wprowadzić zakaz lub ograniczenie zbywania obligacji imiennych. Obligacje mogą mieć postać materialną, a więc występować $\mathrm{w}$ formie dokumentów, jak również postać zdematerializowaną, tzn. nie mieć formy dokumentu, w przypadku gdy emitent tak postanowi. Prawa z obligacji niemających formy dokumentu powstają $\mathrm{z}$ chwilą dokonania zapisu w ewidencji i przysługują osobie w niej wskazanej jako posiadacz tych obligacji (Ofiarski, 2010). 


\section{B. Hadryjańska, J. Mrowicki}

Obligacje przychodowe mogą znaleźć zastosowanie przede wszystkim jako źródło finansowania rozwoju komunalnej sfery użyteczności publicznej, a w szczególności: gospodarki wodno-kanalizacyjnej, utylizacji odpadów oraz transportu publicznego, ponieważ są to dziedziny, które systematycznie przynoszą dochody (Jędrzejewski, 2007).

Obligacje przychodowe różnią się od tradycyjnych obligacji sposobem zabezpieczenia. Są to papiery wartościowe, z których zobowiązanie może być spłacone z przychodów pochodzących $\mathrm{z}$ danego przedsięwzięcia, na które wyemitowano obligacje, a także z całości lub części przychodów z innych przedsięwzięć wskazanych przez emitenta. Specyfiką obligacji przychodowych jest ograniczenie odpowiedzialności dłużnika (emitenta) do wysokości przychodów generowanych przez finansowane $\mathrm{z}$ ich emisji przedsięwzięcie. Zdarza się również, że obligacje te są zabezpieczone poprzez ustanowienie hipoteki na sfinansowanym przez nie majątku. Przychody z inwestycji powinny więc wystarczyć na obsługę i wykup obligacji. Zaletą obligacji przychodowych jest to, że nie obciążają one budżetu gminy. Kolejna pozytywna cecha wynika z faktu, że zobowiązania z tytułu emisji obligacji przychodowych obciążają spółkę-emitenta, dlatego nie są one zaliczane do ogólnego zadłużenia danej jednostki (Jędrzejewski, 2007). A zgodnie z ustawą o finansach publicznych zadłużenie pojedynczego samorządu nie może przekroczyć $60 \%$ jego dochodów w danym roku budżetowym (Kluza, 2011).

Wraz z przystąpieniem Polski do Unii Europejskiej pojawiła się szansa na wykorzystanie funduszy unijnych przez gminy. Działania UE nakierowane na niwelowanie różnic $\mathrm{w}$ poziomie rozwoju społeczno-gospodarczego składają się na unijną politykę regionalną powiązana z polityką strukturalną, określaną inaczej jako polityka spójności. Celem polityki regionalnej UE jest wspieranie restrukturyzacji i modernizacji gospodarek krajów UE w celu wyrównywania różnic w poziomie rozwoju społecznego i gospodarczego pomiędzy najbiedniejszymi i najbogatszymi regionami państw członkowskich (Śliwiński, Grybionko, 2005).

Obligacje przychodowe mogą również służyć gminom jako wkład własny potrzebny do sfinansowania projektów finansowanych z grantów Unii Europejskiej. Gminy, realizując projekty inwestycyjne $\mathrm{z}$ udziałem środków finansowych pochodzących $\mathrm{z}$ funduszy europejskich, muszą wyłożyć od kilku do $50 \%$ wkładu z własnego budżetu, a przy problemach finansowych samorządu często nie jest to możliwe, zwłaszcza w małych gminach wiejskich. Dlatego obligacje przychodowe mogą stać się alternatywą dla nich (Jędrzejewski, 2007).

Liberalizacja wymogów formalnych odnośnie publicznego proponowania nabycia obligacji JST może stanowić pozytywny impuls dla rozwoju tego typu obligacji w Polsce poprzez redukcję kosztów emisji, a konieczność dostosowania się JST do obowiązków związanych z obrotem tymi papierami wartościowymi, stanowi gwarancję bezpieczeństwa dla obligatariuszy (Chojecka, Ostrowski, Stępniewski, 2009a).

Przewagą obligacji, w tym obligacji przychodowych, nad innymi formami finansowania inwestycji w gminach jest ich elastyczność, stosunkowo długi okres zapadalności, czyli finansowania długiem, mniej skomplikowana procedura, wręcz uproszczona. Ważne jest również, że gminy, emitując obligacje, uzyskują również efekt promocyjny i wzmacniają współpracę z instytucjami finansowymi, które pełniąc rolę doradców, przygotowują emisję do wprowadzenia na rynek (Filipiak, 2016).

Pierwsze notowanie obligacji komunalnych na publicznym rynku instrumentów dłużnych CeTO odbyło się 11 grudnia 2003 roku. Były to obligacje na okaziciela wyemitowane prze miasto Poznań. Aby uzyskać zadowalający poziom płynności obrotu 
emitowanych papierów ustalono niski nominał obligacji (100 zł), a konstrukcja oprocentowania bazowała na stopie WIBOR. W I kwartale 2014 r. wartość rynku obligacji komunalnych osiągnęła wartość 18,33 mld zł. W ujęciu rocznym nastąpił 17,4\% przyrost wartości tego segmentu.

Debiut obligacji przychodowych w Polsce miał miejsce w 2005 r., chociaż samorządy mogły korzystać z tego instrumentu już pięć lat wcześniej. Pierwsza, obligacje przychodowe jako źródło finansowania inwestycji komunalnych, wykorzystała Bydgoszcz. Inwestorem była komunalna spółka Miejskie Wodociągi i Kanalizacja, a pieniądze na obsługę i wykup obligacji pochodziły z wpływów z eksploatacji wodociągów (Jędrzejewski, 2007).

Do 2015 roku przeprowadzono emisje tylko 7 obligacji przychodowych m.in. w Bydgoszczy, Gdańsku i Lublinie, a żadna z tych emisji nie dotyczyła gmin wiejskich.

Obligacje przychodowe są wciąż postrzegane w samorządzie terytorialnym jako nieznana i niepewna metoda pozyskiwania dodatkowych pieniędzy. Wielu samorządowców interesuje się obligacjami. Jednak znaczna ich liczba nie posiada wystarczającej wiedzy w tym przedmiocie. Obawiają się zapewne, że jest to produkt drogi i zbyt skomplikowany, podczas gdy wiele przemawia za tym, że jest to bardzo korzystne źródło pozyskiwania funduszy na realizację inwestycji (Jędrzejewski, 2007).

\section{Gminy wiejskie wobec możliwości wykorzystania obligacji przychodowych - wyniki badań empirycznych}

Badania empiryczne zostały przeprowadzone w I połowie 2017 roku, a podstawowym narzędziem badawczym był kwestionariusz ankietowy. Zawierał on 10 pytań skierowanych do wszystkich 606 gmin wiejskich będących członkami Związku Gmin Wiejskich (ZGW). Kwestionariusz został rozesłany drogą mailową przy czynnym udziale dyrekcji ZGW.

Zwrotnie otrzymano 132 ankiety od gmin wiejskich znajdujących się na terenie wszystkich województw (zwrotność ankiet wynosi około 22\%). Najwięcej ankiet uzyskano z województwa mazowieckiego (19), a najmniej - z województw: lubuskiego, opolskiego i podkarpackiego - po 2 ankiety. Z województwa wielkopolskiego i łódzkiego uzyskano po 17 kwestionariuszy, z województw dolnośląskiego i kujawsko-pomorskiego - po 13 ankiet, z województwa lubelskiego -9 ankiet, z małopolskiego -8 ankiet, z podlaskiego i śląskiego - po 7 ankiet, ze świętokrzyskiego - 6 ankiet, pomorskiego - 4 ankiety, a z warmińskomazurskiego i zachodniopomorskiego - po 3 ankiety.

Przeważająca większość gmin wiejskich w Polsce (ponad 90\%) korzysta z dotacji unijnych, kredytów i pożyczek, aby sfinansować inwestycje samorządowe (rys. 1). Z obligacji komunalnych skorzystało 38 gmin, z obligacji przychodowych - tylko 2 gminy. Obligacje przychodowe więc nie pozostają w sferze zainteresowań gmin wiejskich jako źródło finansowania ewentualnych inwestycji (aż 98\% respondentów nie wykorzystywało takiego źródła). 


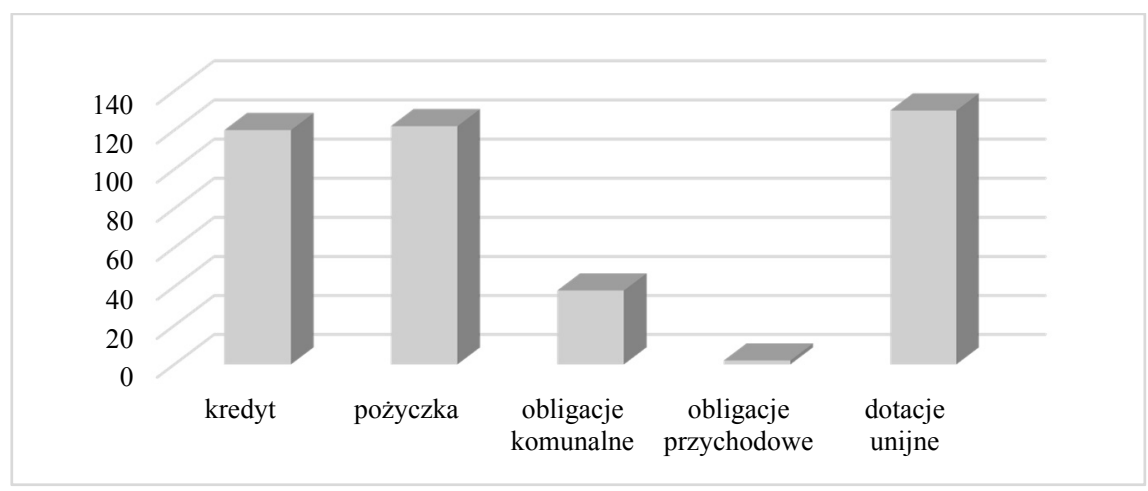

Rys. 1. Finansowanie inwestycji gmin wiejskich w Polsce z zewnętrznych źródeł

Fig.1. Financing municipal investments in Poland from various external sources

Źródło: badania własne.

Dwie gminy, które korzystały z obligacji przychodowych wybrały ten instrument ze względu na konieczność zrealizowania inwestycji gminnych oraz możliwość uniknięcia ograniczeń w wysokości zadłużania się wynikających z art. 243 Ustawy o finansach publicznych. Gminy te przeznaczyły emisję obligacji przychodowych na poprawę infrastruktury drogowej oraz na działania związane $\mathrm{z}$ ochroną środowiska.

Główną przyczyną, dla której gminy wiejskie nie korzystają z obligacji przychodowych jest brak informacji o dostępności takiego instrumentu finansowego oraz obawa przed nadmiernym zadłużeniem gminy (30\% gmin wskazało takie przyczyny) (wykres 2). 15\% respondentów wykazało, że nie korzysta $\mathrm{z}$ obligacji przychodowych ze względu na skomplikowaną procedurę oraz trudności w znalezieniu nabywców takich papierów dłużnych. Ważnym powodem niestosowania obligacji przychodowych okazały się niejasności prawne Ustawy o finansach publicznych, a także brak specjalistycznej kadry oraz duże koszty organizacji emisji obligacji przychodowych. Gminy wiejskie nie korzystały $\mathrm{z}$ obligacji przychodowych $\mathrm{z}$ powodu braku takiej potrzeby oraz braku inwestycji które w przyszłości generowałyby przychody do wykupu obligacji przychodowych. Ponadto kilka gmin uważa, że obecnie stosowane rozwiązania są wystarczające, a pozyskiwać środki na inwestycje mogą na atrakcyjniejszych warunkach np. kredyt może być szybszym i tańszym źródłem, opartym o znane już procedury. 


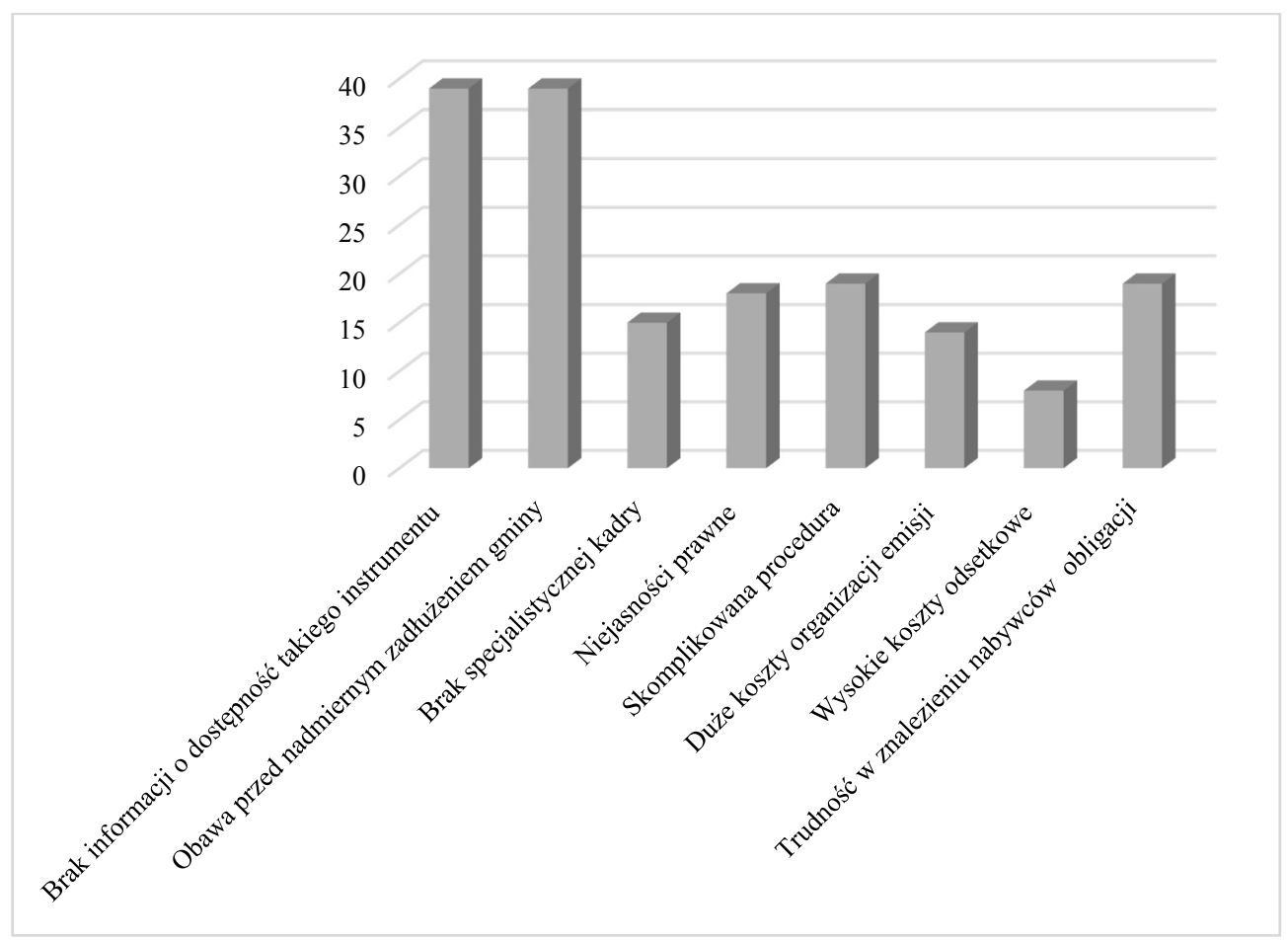

Rys. 2. Powody niekorzystania z obligacji przychodowych przez gminy wiejskie w Polsce

Fig. 2. Reasons for not using income bonds by rural communities in Poland

Źródło: badania własne.

W związku z powyższym wydaje się niezbędnym, żeby organizować szkolenia o możliwościach wykorzystania obligacji przychodowych w gminach. Będzie to miało znaczenie szczególnie w najbliższej perspektywie zmniejszania się wsparcia unijnego dla gmin. Istnieje duże prawdopodobieństwo, że w ciagu kilku następnych lat poziom środków unijnych będących źródłem istotnej części dochodów gmin wiejskich będzie znacznie mniejszy, co wymusi na włodarzach jednostek samorządu terytorialnego stosowanie innych instrumentów finansowania ich działalności.

\section{Podsumowanie}

Podstawową jednostką samorządu terytorialnego jest gmina. Wykonuje ona wszystkie zadania samorządu terytorialnego niezastrzeżone dla innych jednostek samorządowych. Dla właściwego funkcjonowania gmina potrzebuje w związku z tym środków finansowych, które mogą pochodzić z różnych źródeł. Mogą to być środki własne gminy wypracowane głównie z podatków i opłat lokalnych, które są wykorzystywane, obok dotacji celowych i subwencji, do realizacji zadań bieżących. Do działalności inwestycyjnej gminy potrzebują zewnętrznych źródeł pozabudżetowych, takich jak pożyczek, kredytów, czy emisji obligacji. 


\section{B. Hadryjańska, J. Mrowicki}

Gminy, aby wygenerować kapitał potrzebny do inwestycji, mają możliwość emisji obligacji komunalnych i przychodowych, które są alternatywą dla pożyczek i kredytów. Niestety gminy wiejskie nie korzystają masowo z tego typu instrumentów i przez kilkanaście lat dostępu do obligacji przychodowych zaledwie dwie badane gminy wyemitowały je.

Poprzez badania empiryczne autorzy chcieli dowiedzieć się o rzeczywistych powodach braku zainteresowania emisją i sprzedażą obligacji przychodowych przez gminy wiejskie. $\mathrm{Z}$ zebranego materiału ankietowego wynika, że podstawowym źródłem pozabudżetowego finansowania dla gmin są dotacje unijne oraz kredyt i pożyczka, które są znanym i sprawdzonym sposobem realizowania inwestycji gminnych. Gminy nie korzystają z obligacji przychodowych, ponieważ nie mają wiedzy na temat takiego instrumentu finansowego, a także obawiają się nadmiernego zadłużenia gminy. Wydaje się, że ważnym powodem takiego stanu rzeczy jest ostrożność gmin oraz niechęć do korzystania z instrumentów, które nie są im dobrze znane. Celem szerzej prowadzonych badań jest wypracowanie takiej formuły instrumentów dłużnych, aby ułatwić oraz zwiększyć możliwości inwestycyjne szczególnie małych gmin wiejskich, co jest szczególnie ważne w świetle ogromnych potrzeb rozwojowych i ograniczonych możliwości ich finansowania przez gminy wiejskie, a także bliskiej perspektywy bezzwrotnej pomocy unijnej. Prowadzone badania pokrywają się z postulatem Związku Gmin Wiejskich utworzenia Krajowego Funduszu Rozwoju Obszarów Wiejskich, którego jednym z instrumentów funkcjonowania mogłyby być obligacje przychodowe.

\section{Literatura}

Borodo, A. (2014). Polskie prawo finansowe. Zarys ogólny, Toruń, Dom Organizatora.

Bukowski, Z., Jędrzejewski, T., Raczka, P. (2003). Ustrój samorządu terytorialnego, Toruń, Dom Organizatora.

Chojecka, I., Ostrowski, J., Stępniewski, M., Śliwiński, P. (2009a). Emisja obligacji przychodowych, w: Obligacje komunalne. Zagadnienie prawne, finansowe i praktyczne. Stan na 30 kwietnia 2009, praca zbiorowa pod redakcją P. Śliwińskiego, M. Stępniewskiego, Warszawa, Twigger.

Chojecka, I., Ostrowski, J., Stępniewski, M., Śliwiński, P. (2009b). Niepubliczna emisja obligacji komunalnych. W: Obligacje komunalne. Zagadnienie prawne, finansowe i praktyczne. Stan na 30 kwietnia 2009, praca zbiorowa pod redakcją P. Śliwińskiego, M. Stępniewskiego, Warszawa, Twigger.

Dolnicki, B. (2009). Samorząd terytorialny, Warszawa, Wolters Kluwer.

Dylewski, M., Filipiak, B., Gorzałczyńska-Koczkodaj, M., Zioło, M. (2014). Finanse publiczne. Aspekty teoretyczne i praktyczne, Warszawa, Wydawnictwo C.H. Beck.

Europejska Karta Samorządu Terytorialnego, sporządzona w Strasburgu dnia 15 października 1985 r. (Dz. U. z 1994 r. nr 124, poz. 607).

Filipiak, B.Z. (2016). Produkty strukturyzowane jako szczególny rodzaj produktów finansujących zadania inwestycyjne JST. W: B.Z. Filipiak, M. Zioło (red.), Współpraca jednostek samorządu terytorialnego z instytucjami finansowymi. Uwarunkowania-procesy-decyzje, Warszawa, Difin, 154-156, 158.

Fleszer, D. (2011). Samorząd terytorialny i jego zadania w świetle uregulowań prawnych - rozbieżności interpretacyjne. W: M. Stefański, H. Stępień (red.), Gospodarka i finanse gmin w Polsce. Wybrane zagadnienia, Włocławek, Wyższa Szkoła Humanistyczno-Ekonomiczna we Włocławku.

Gonet, W. (2016). Realizacja zadań publicznych przez gminy. W: A. Zalcewicz (red.), Finansowanie zadań publicznych służących zaspokajaniu potrzeb wspólnot samorządowych, Warszawa, Wydawnictwo Poltext.

Izdebski, H. (2009). Samorząd terytorialny. Podstawy ustroju i działalności, Warszawa, Wyd. LexisNexis.

Jędrzejewski, L. (2007). Gospodarka finansowa samorządu terytorialnego w Polsce. Wybrane zagadnienia, Bydgoszcz-Gdańsk, Oficyna Wydawnicza Branta.

Kluza, K. (2011). Dostępność finansowa dla samorządów w okresie spowolnienia gospodarczego w latach 20082010. W: A. Alińska, B. Pietrzak (red.), Finanse publiczne a kryzys ekonomiczny, Warszawa, CeDeWu.

Konstytucja Rzeczypospolitej Polskiej z 2 kwietnia 1997 RP, art. 16 ust 1.; art. 164 ust. 1. 
Kornberger-Sokołowska, E. (2010). Budżety jednostek samorząu terytorialnego w aspekcie decentralizacji i regionalizacji finansów publicznych. W: E. Ruśkowski (red.), Prawo finansowe sektora finansów publicznych, Warszawa, Oficyna Wydawnicza Wolters Kluwer.

Kotowska, E. (2016). Doskonalenie metod i narzędzi przejrzystej polityki budżetowej w jednostkach samorządu terytorialnego. W: A. Zalcewicz (red.), Finansowanie zadań publicznych służących zaspokajaniu potrzeb wspólnot samorządowych, Warszawa, Wydawnictwo Poltext.

Kozuń-Cieślak, G. (2008). Obligacje komunalne. Instrument dłużny dla jednostek samorządu terytorialnego, Warszawa, Wydawnictwo Naukowe PWN.

Ofiarski, Z. (2010). Prawo finansowe, Warszawa, Wydawnictwo C.H. Beck.

Oświadczenie Rządowe z dnia 14 lipca 1994 r w sprawie ratyfikacji przez Rzeczpospolitą Polską Europejskiej Karty Samorządu Terytorialnego, sporządzonej w Strasburgu dnia 15 października 1985 r. (Dz.U. z 1994 r. nr 124 , poz. 608).

Pająk, K. (2011). Samorząd terytorialny i jego wewnętrzna transformacja, Toruń, Wydawnictwo Adam Marszałek.

Pastuszka, S. (2016). Uwarunkowania polityki budżetowej powiatów województwa świętokrzyskiego w latach 2004-2014. W: S. Pastuszka, A. Kasińska-Metryka (red.), Ekonomiczne i polityczne uwarunkowania rozwoju samorządu terytorialnego, Toruń, Wydawnictwo Adam Marszałek.

Rozporządzenie Rady Ministrów z 7 sierpnia 1998 r. w sprawie utworzenia powiatów, Dz.U. nr 103, poz. 652.

Sadowska, B. (2011). Struktura dochodów gmin i możliwości jej kształtowania. W: M. Stefański, H. Stępień (red.), Gospodarka i finanse gmin w Polsce. Wybrane zagadnienia, Włocławek, Wyższa Szkoła HumanistycznoEkonomiczna we Włocławku.

Samorząd powiatowy w Polsce - raport ZPP, Związek Powiatów Polskich, Warszawa (2013).

Sprawozdanie $\mathrm{z}$ wykonania budżetów gmin za grudzień 2016. Pobrane 17 września 2017 z: http://www.mf.gov.pl/ministerstwo-finansow/dzialalnosc/finanse-publiczne/budzety-jednostek-samorzaduterytorialnego/sprawozdania-budzetowe.

Śliwiński, P. (2009). Porównanie kredytu i emisji obligacji, w: Obligacje komunalne. Zagadnienie prawne, finansowe i praktyczne. Stan na 30 kwietnia 2009, praca zbiorowa pod redakcją P. Śliwińskiego, M. Stępniewskiego, Warszawa, Twigger.

Śliwiński, P., Grybionko, K. (2009). Wykorzystanie obligacji komunalnych w realizacji inwestycji realizowanych ze środków unijnych. W: Obligacje komunalne. Zagadnienie prawne, finansowe i praktyczne. Stan na 30 kwietnia 2009, praca zbiorowa pod redakcją P. Śliwińskiego, M. Stępniewskiego, Warszawa, Twigger.

Śliwiński, P., Ostrowski, J., Stępniewski, M. (2005). Obligacje komunalne i ich rola w finansowaniu inwestycji, Warszawa, Twigger.

Ustawa z 8 marca 1990 r. o samorządzie gminnym, Dz. U. nr 16, poz. 1591 (Obwieszczenie Marszałka Sejmu Rzeczypospolitej Polskiej z dnia 17 marca 2016 r. w sprawie ogłoszenia jednolitego tekstu o samorządzie gminnym, Dz.U. z 2016 r., poz. 446).

Ustawa z dnia 13 listopada 2003 r. o dochodach jednostek samorzadu terytorialnego, Dz. U. z 2003 r., nr 203 , poz. 1966 (Obwieszczenie Marszałka Sejmu Rzeczypospolitej Polskiej z dnia 18 marca 2015 r. w sprawie ogłoszenia jednolitego tekstu o samorządzie gminnym, Dz.U. z 2015 r., poz. 513).

Ustawa z dnia 27 sierpnia 2009 r. o finansach publicznych, Dz.U. 2009 nr 157 poz. 1240 (Obwieszczenie Marszałka Sejmu Rzeczypospolitej Polskiej z dnia 14 października 2016 r. w sprawie ogłoszenia jednolitego tekstu ustawy o finansach publicznych, Dz.U. 2016 poz. 1870)

Ustawa z dnia 29 czerwca 1995 r. o obligacjach, Dz.U. z 2001 r., Nr 120, poz. 1300 z późn. zm.

Ustawa z dnia 5 czerwca 1998 r. o samorządzie powiatowym, Dz. U. nr 91, poz. 578 ze zm.

Wernik, A. (2014). Finanse publiczne. Cele, struktury, uwarunkowania, Warszawa, PWE.

Zioło, M. (2016). Specyfika funkcjonowania jednostek samorządu terytorialnego a popyt na usługi finansowe Uwarunkowania-procesy-decyzje. (w:) B.Z. Filipiak, M. Zioło (red.), Współpraca jednostek samorządu terytorialnego z instytucjami finansowymi. Uwarunkowania-procesy-decyzje, Warszawa, Difin.

Ziółkowska, W. (2012). Finanse publiczne. Teoria i zastosowanie, Poznań, Wydawnictwo WSB.

Zobowiązania według papierów dłużnych jednostek samorządu terytorialnego wg tytułów dłużnych w latach 2010-2 kwartały 2012. Ministerstwo Finansów, październik 2012, Warszawa. 